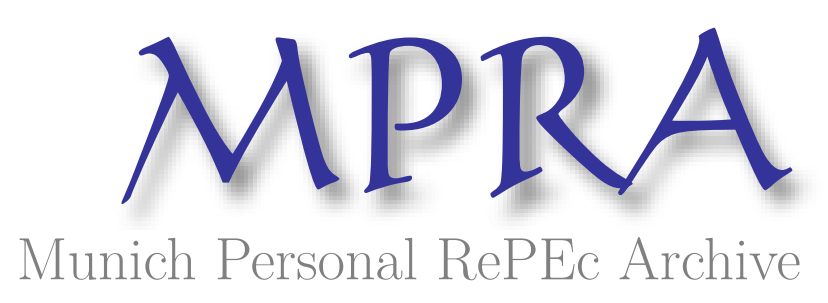

\title{
Economic Structure and Vulnerability to Organised Crime: Evidence from Sicily
}

Lavezzi, Andrea Mario

University of Palermo

2008

Online at https://mpra.ub.uni-muenchen.de/50114/

MPRA Paper No. 50114, posted 08 Oct 2013 11:10 UTC 


\title{
Economic Structure And Vulnerability to Organized Crime: Evidence from Sicily
}

\author{
Andrea Mario Lavezzi*
}

\begin{abstract}
The economic analysis of organized crime suggests that some economic activities are particularly vulnerable to penetration by criminal organizations. This paper provides an analysis of the structure of the Sicilian economy and shows that, when compared to other Italian regions, it is characterized by a disproportionate presence of such activities. In particular, the economy of Sicily appears characterized by: (i) a large dimension of traditional sectors, such as the Construction sector, which also has a strong territorial specificity; (ii) a large presence of small firms; (iii) a low level of technology; (iii) a large public sector. The joint presence of these features creates fertile soil for the typical activities of organized crime, such as extortion and cartel enforcement. Hence, we propose an alternative explanation of the persistence of organized crime with respect to explanations based on cultural and social factors.
\end{abstract}

Keywords: Organized Crime, Economic Structure, Sicilian Mafia, Economic Development.

\section{Introduction}

Organized crime is still remarkably active in Italy, especially in the Southern regions of Campania, Apulia, Calabria and Sicily. The recent survey by Censis (2007) reports that

\footnotetext{
${ }^{*}$ University of Palermo and CICSE. Address: Dipartimento Studi su Diritto, Politica e Societá, Piazza Bologni 8, 90133 Palermo, Italy. Tel. ++39 091 6625600, Fax ++39 091 6112023, Email: mario.lavezzi@unipa.it. This is an Author's Accepted Manuscript of an article published in Global Crime, 9, 2008 [copyright Taylor \& Francis], available online at: http://www.tandfonline.com/doi/abs/10.1080/17440570802254312\#. UkBMG4pdWv4
} 
about $77 \%$ of resident population in these regions (about 13 million people) lives in towns in which the presence of organized crime is recorded.

This paper aims to contribute to the explanation of the diffusion and persistence of organized crime. In particular, it analyzes the relationship between the structure of the economy in Sicily and the diffusion of organized crime, building on some insights from the economic analysis of criminal organizations. ${ }^{1}$ Our empirical analysis shows that the Sicilian economy, compared to the economy of other Italian regions, appears particularly vulnerable to penetration from organized crime, being characterized by: (i) a relatively high shares of traditional sectors and economic activities strongly related to the territory, like the Construction sector; (ii) a relatively small firm's size, (iii) a relatively low technological level and, (iii) a large dimension of the public sector. The joint presence of these characteristics, as the theory suggests, makes the economy fertile soil for the propagation of typical activities performed by criminal organization, like extortion and cartel enforcement, the latter being particularly important in the adjudication of public works.

These results provide an alternative explanation to theories on the persistence of organized crime based on cultural and social factors (see e.g. Putnam (1993), pp. 146-148), and may also be relevant for studies on transplantation of organized crime ( Varese (2006)). Indeed, the evidence provided in Varese (2006) is consistent with the thesis of this paper. A territory may favor the diffusion of organized crime when the structure of its economy have certain characteristics. The economy of Bardonecchia, a city in Northern Italy where organized crime from Calabria successfully entrenched, was heavily based on Construction at the time of transplantation. On the contrary, the economy of Verona, another city in Northern Italy where the entrenchment failed, was more based on hi-tech, export-oriented firms.

The paper is organized as follows. Section 2 introduces the theoretical background; Section 3 contains the results of the empirical analysis; Section 4 concludes.

\footnotetext{
${ }^{1}$ Part of the results in this paper are in Lavezzi (2008). With respect to Lavezzi (2008), the theoretical framework has been thoroughly re-elaborated, new data have been considered, and the empirical analysis has been strengthened by several tests on the statistical significance of the results.
} 


\section{Theory}

The seminal contributions of Schelling (1967) and Schelling (1971) provide an analysis of the economic activities which, for their characteristics, can more easily fall under the control of organized crime. This requires a preliminary definition of the goals of the criminal organization.

According to Schelling (1967), p. 182, criminal organizations such as the Sicilian Mafia can be compared to governments in the sense that, like governments: "organized crime ... seeks not only influence, but exclusive influence ... or at least a stable jurisdictional sharing with other authorities." (emphasis added). In fact, the activities of government and control, typically performed by the State, imply the definition of rules, the settlement of conflicts, the imposition of discipline, etc. Thus, these activities must necessarily be performed under a monopoly regime in order to be effective. ${ }^{2}$ These characteristics are clearly traceable in the Sicilian Mafia: "in Sicily there is a clear geographic division; individual families have specific areas in which they have the sole operating authority" ( Gambetta and Reuter (1995), p. 119).

The actions undertaken by organized crime to reach its goals of controlling and governing take different shapes. In particular, with respect to the control of the economy, the Mafia: (i) practices extortion, and (ii) plays the role of cartel enforcer. Both activities have an important common economic consequence: they reduce competition. ${ }^{3}$ Let us pause on the description of these activities and on their consequences.

As for extortion, firms pay the Mafia in order to remain active on the market. From this point of view, firms "buy protection" ( Gambetta (1993)) in principle from other organizations but, in practice, first and foremost from the criminal organization itself, which may credibly threat to cause damages, economic and personal, to the firms refusing to pay ( Schelling (1971), p. 185).

Besides extortion, the Mafia also plays the more complex activity of enforcer of col-

\footnotetext{
${ }^{2}$ Indeed, in actual situations there are no territories where two jurisdictions apply.

${ }^{3}$ Although unified by this aspect, in the present discussion we keep the two activities separated as there is at least an important difference: extortion does not necessarily imply some kind of interaction (e.g. strategic) among the firms involved, as is typically the case of firms belonging to the various cartels overseen by the Mafia.
} 
lusive agreements, which are particularly relevant in public procurement. For example, Gambetta and Reuter (1995), pp. 124-125, describe the mechanism by which cartel members agree in advance on the firm which will adjudicate the public work, and make fictitiously high offers to let the chosen one prevail. This occurs within a broader agreement on the rotation of cartel firms in the adjudication of public contracts. The enforcement of the agreements is guaranteed by the organization, which levies a "tribute" on the participating firms. ${ }^{4}$

In both cases the payment to the organization appears as a price paid by the firms in order to reduce competition. ${ }^{5}$ This is more apparent in the case of the cartels, in which firms buy a privileged position with respect to outsiders. ${ }^{6}$ However, also in the case of extortion where coercion appears more important, it cannot be excluded that the money paid is part of an agreement by which the firm buys protection not only from possible damages, but also from possible competitors.

Gambetta (1993) discusses at length instances in which payments to the criminal organization appear voluntary. For example, he argues that potential entrants in a market can be considered as extorted, if they wanted to enter. On the contrary, incumbents: "pay for protection ... to deter new competitors" ( Gambetta (1993), p. 32). ${ }^{7}$ In any case, although the dividing line between coercion and will cannot always be easily drawn, the payment of protection money represents a de facto reduction in competition as it

\footnotetext{
${ }^{4}$ Cartels of firms may not be strictly related to public works, as in the case of the fish market in Palermo described in Gambetta (1993), pp. 202-206.

${ }^{5}$ Note that, in both contexts, being a monopolist on the part of the organization is essential. In the case of extortion, monopolistic power is crucial because: "large-scale systematic extortion cannot really stand competition any more than can a local taxing authority" ( Schelling (1971), p. 185). In the case of cartel enforcement, since the activity clearly requires the mentioned features of "control" and "government", it cannot but be exclusive.

${ }^{6}$ For a detailed discussion on the types of cartel that may involve a criminal organization, see e.g. Alexander (1997).

${ }^{7}$ Gambetta (1993), p. 199, reports a declaration of a firm partner from Palermo: "The least those who protect you can do is offer to discourage competitors should they want to enter your territory".
} 
constitutes a barrier to entry for firms unwilling to pay. ${ }^{8}$

Once recognized the main consequences of criminal control over economic activities, in particular on the level of competition, there remains the task of identifying the causes that make some activities more easily subjected to control and monopolization, which represents the main focus of this paper (but reduction in competition will be recalled later).

Let us consider the characteristics that, cœeteris paribus, make a firm more likely to become victim of extortion. Following Fiorentini (2000), we can claim that the probability of being extorted is higher: ${ }^{9}$

1. the higher the difficulty of obtaining protection from others organizations or institutions, as is the case of firms operating in areas in which legal institutions are weak or corrupted $;^{10}$

2. the higher the observability of output and profits, which makes more difficult for the firm to hide these magnitudes and potentially escape from the payment of protection money;

3. the higher the territorial specificity of the firm's assets, given the importance of control on territorial basis typically exerted by the organization;

4. the higher the capacity to transfer the payment of the tribute on the final price,

\footnotetext{
${ }^{8}$ Gambetta (1993), p. 20, describes another instance of voluntary payments to the Mafia: "protection money may be willingly paid" by individuals engaged in economic transactions where parties do not trust each other. In this case the mafioso can provide insurance against opportunistic behavior.

${ }^{9}$ In what follows we list arguments related to legal firms, and arguments related to illegal businesses that can be relevant for legal activities too.

${ }^{10}$ Italy is in general a country in which institutions are weak at ensuring law enforcement. For example, the World Bank (www.worldbank.org/wbi/governance) assigns to Italy in 2005 the score of 0.51 , referred to the interval $(-2.5,2.5)$, for the indicator "rule of law", which provides information on: "the extent to which agents have confidence in and abide by the rules of society, and in particular the quality of contract enforcement, the police, and the courts, as well as the likelihood of crime and violence" ( Kaufman et al. (2006), p. 4). This places Italy at the seventyfourth position in the world. To the best of my knowledge no such indicators exist at regional level, although there exists widespread consensus that the overall institutional quality of regions in Southern Italy is poorer than in the North (see, e.g. Leonardi (2002)).
} 
hence the lower is the level of competition (which, as remarked, is in any case endogenously reduced by the presence of extortionary practices);

5. the smaller the dimension of the firm, as this implies a lower number of employees and, therefore, a lower probability that extortion is revealed outside the firm and, in addition, as: "in large organizations too many people have to sign the checks, initial the vouchers, audit the books, scrutinize budgets, take inventory ... The small independent entrepreneur ... would be more able to meet the demands than a complex organization would be" ( Schelling (1971), p. 182).

Instead, following Gambetta and Reuter (1995), we can list the factors that make more probable the formation of cartels enforced by the criminal organization:

1. the higher the territorial characterization of the economic activity, like that of firms belonging to the sectors of "construction, transport, and street-hawkers" ( Gambetta and Reuter (1995), p. 122), for the mentioned necessity of controlling the territory;

2. the higher the possibility for cartel members to share the clients. An example is represented by suppliers of the Public Administration, in which firm X supplies schools, firm Y supplies hospitals, etc; ${ }^{11}$

3. the higher is the possibility, if clients are not numerous and therefore sharing them is not viable, to create "queues" among the cartel firms, for instance to supply the same client repetitively in time. The Public Administration can be quoted as a case of a unique client which can be supplied by many firms in time, for instance because it can contract out different works, services, etc, following the procedure described above.

It can be immediately noted an overlapping among the two series of characteristics concerning the importance of the "territorial" aspect of the economic activity. ${ }^{12}$ Moreover,

\footnotetext{
11 "Relative to private customers, public institutions are fewer, take out longer-term contracts, buy fixed quantities, are generally slack about quality, careless about price and corruptible. In short, they are easy to share" ( Gambetta and Reuter (1995), pp. 123-124).

${ }^{12}$ The most obvious candidate in this respect is the Construction sector. Kelly (1999), pp. 90-95,
} 
as an implication, it is possible to conjecture that the technological level of firms which are more likely to suffer Mafia conditioning will be low, as low will be the skill level of workers.

In fact, a high technological level can make monitoring of the activity problematic, and is typically associated to relatively complex organizational structures and/or relatively high dimensions (for instance due to the fixed R\&D costs). As Reuter (1987), p. 7, points out: "Racketeers are not believed to be influential in industries containing large corporations or involving high technology. Rather, they are influential in those essentially local activities where small, family-based enterprises are particularly important." In addition, a small firm size is typically associated to little investments in human capital in the form of on-the-job training (see, e.g., ISTAT (1996) on Italy), and this can limit the absorption of new technologies as human capital is an important pre-requisite for the introduction of hi-tech capital, as remarked since the seminal contribution of Nelson e Phelps (1966).

Finally, as noted, it appears that the presence of the public sector can be associated to the emergence of economic activities desirable by the Mafia, a point generally found in the economic literature on corruption: "The greater the presence of the state, the greater is the potential for corruption" ( Del Monte e Papagni (1998), p. 380).

As a consequence, it is possible to sketch the profile of the firm type whose diffusion can favor the propagation of Mafia conditioning on the economic activity. This firm will be:

1. small;

2. belonging to traditional and/or low-tech sectors;

3. engaged in activities strongly related to the territory;

4. active in an area where the public sector is large (and legal institutions are weak). discusses other aspects making the Construction sector permeable to organized crime with respect to the experience of the US. Schneider and Schneider (2003), pp. 90-91, point out that the Construction sector is also tightly linked to the public sector, and therefore represents an ideal target for criminal organizations. 
In the light of this line of reasoning, in Section 3 we present the results of an empirical analysis of the structure of the Sicilian economy, in order to evaluate if and to what extent it presents those characteristics that make it vulnerable to the propagation of organized crime, with respect to other Italian regions.

\section{Empirical Analysis}

In this section we present an empirical analysis of the Sicilian economy divided in two parts:

1. analysis of the recent dynamics of per capita income and labor productivity;

2. analysis of the structure of the economy in terms of:

- sectoral composition of employment;

- firm size;

- technological level.

\subsection{On the Recent Dynamics of the Sicilian Economy}

Figures 1 and 2 respectively report the dynamics of per capita GVA and labor productivity (per worker GVA), measured with respect to the Italian average. ${ }^{13}$ We compare Sicily (SIC) to the average of Center-North regions (CN), Lombardy (LOM, which represents the most dynamic region), to the average of the other Southern regions (SOUTH), and to the average of Southern regions in which the presence of organized crime is not pervasive $\left(\mathrm{SOUTH}^{*}\right) \cdot{ }^{14}$

\footnotetext{
${ }^{13}$ Data are from the CRENOS database (http://www.crenos.it). They cover the period 1970-2004 and are expressed at 1995 constant prices. These data are based on official ISTAT (Italian national statistical institute) statistics but, compared to them, offer regional time series at a more disaggregated level. In what follows we consider the period 1970-1994, for a not complete comparability of the 1970-1994 e 19952004 subperiods. Our findings are not substantially altered by the analysis of the subperiod 1995-2004. For simplicity, we will indicate the dimension of the labor force with "employed", instead of "units of labor", which refer to numbers of equivalent full-time employed. All computations in this paper have been performed in $R$ (www.r-project.org); codes and data are available at: http://www.unipa.it/ lavezzi.

${ }^{14}$ See Appendix A for the list of regions and sectors, and the composition of the macroregions.
} 


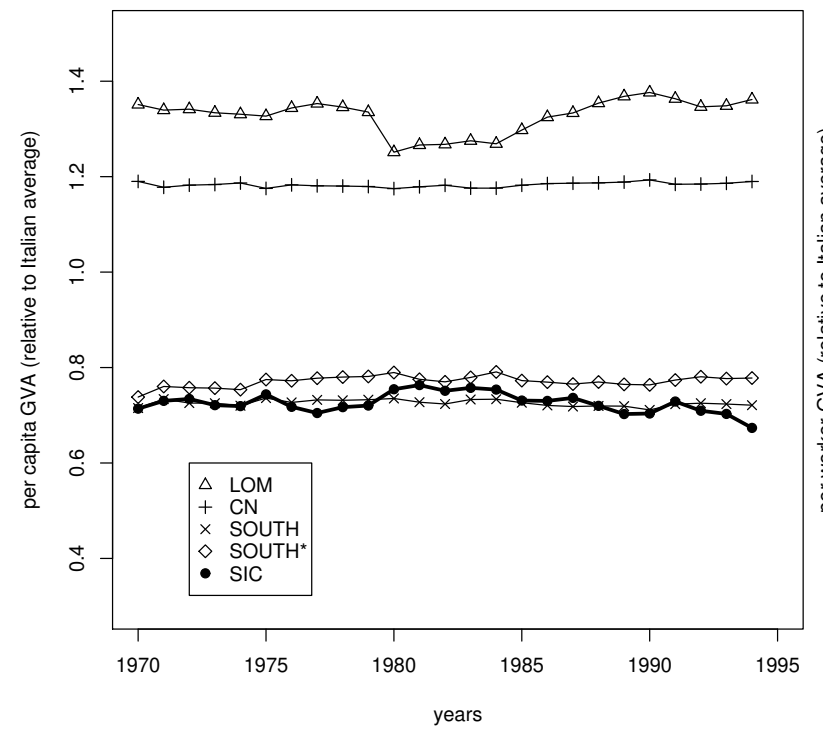

Figure 1: Per capita GVA: 1970-1994

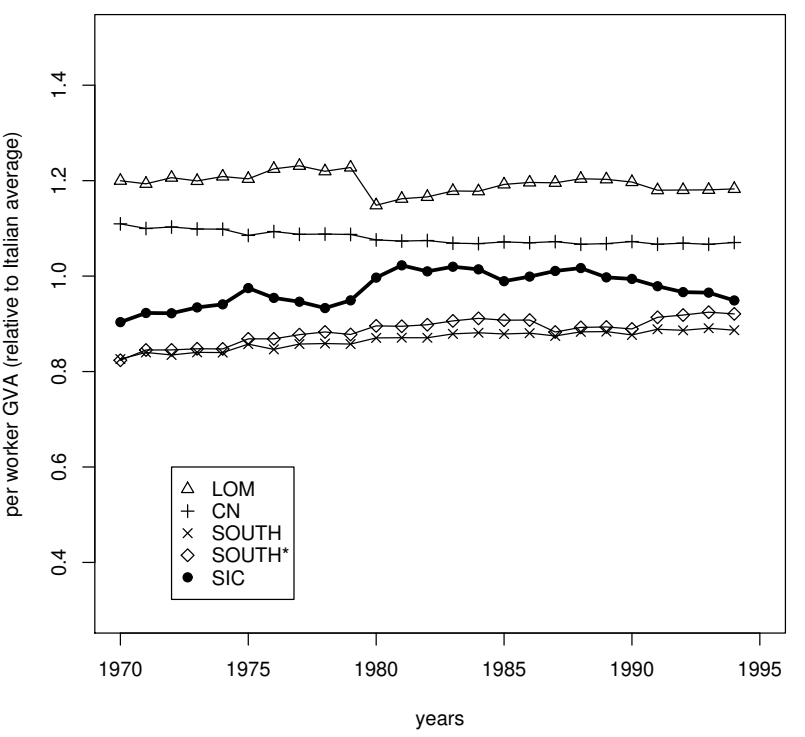

Figure 2: Per worker GVA: 1970-1994

In the context of the well-known Italian economic dualism, with the regions in the North-Center outperforming the regions in the South especially in terms of per capita GVA, the economy of Sicily is located at the bottom of the distribution in terms of per capita GVA, while its performance in terms of labor productivity appears slightly better. ${ }^{15}$ Note that the macroregion of SOUTH* performs better than the macroregion of SOUTH, and that LOM clearly stands out as the richest and most productive region.

This preliminary part of the analysis reveals that, on aggregate, the Sicilian economy in the period considered is characterized by substantial backwardness with respect to other Italian regions. This contributes to setting the stage for the subsequent analysis but, at first sight, it could also be considered as part of the explanation of the diffusion of organized crime, in a chain of reasoning that goes from economic backwardness to the diffusion of organized crime, through the institutional weakness associated to poverty. ${ }^{16}$

\footnotetext{
${ }^{15}$ The higher cross-regional dispersion in terms of per capita GVA depends on the different employed/population ratios between Northern and Southern Italy. For example, between 1970 and 1994 the ratio employed/population ratio in Sicily was about 30\%, while in the regions with the highest levels of per capita GVA it was about $50 \%$.

${ }^{16}$ The idea that the level of economic development is a fundamental prerequisite for a high institutional quality is commonly indicated as the "modernization" hypothesis. See, e.g. Putnam (1993), pp. 83-86, for a discussion on institutional quality in Italian regions and some caveats on this reasoning. We will return on the issue of causality in Section 4.
} 
In what follows we propose a more disaggregated study in order to highlight that, from an economic point of view, what can be relevant to favor the diffusion of organized crime is the structure of the economy, and not only its relative state of backwardness. In fact, the structure of the economy may be the common factor causing poverty and the diffusion of organized crime.

\subsection{On the Structure of the Sicilian Economy}

The analysis of the structure of the Sicilian economy is conducted through an analysis of:

(i) the sectoral distribution of the labor force, and of its evolution in the period considered;

(ii) the size distribution and (iii) the technological level of Sicilian firms. The comparison will be conducted with respect to ITA, LOM, SOUTH, and SOUTH*.

\subsubsection{Sectoral Employment Shares}

Table 1 highlights the sectoral evolution of the labor force in the period 1970-1994. 


\begin{tabular}{lrr|rr|rr|rr|rr}
\hline & \multicolumn{2}{c}{ ITA } & \multicolumn{2}{c}{ LOM } & \multicolumn{2}{c}{ SOUTH } & \multicolumn{2}{c}{ SOUTH* } \\
\hline Sector & 1970 & 1994 & 1970 & 1994 & 1970 & 1994 & 1970 & 1994 & 1970 & 1994 \\
\hline AG & 23.67 & 8.74 & 6.33 & 3.40 & 36.24 & 13.54 & 37.88 & 12.53 & 30.10 & 12.86 \\
EN & 2.71 & 2.03 & 5.00 & 3.10 & 1.48 & 1.76 & 1.53 & 2.01 & 1.32 & 1.63 \\
\hline MI1 & 1.73 & 1.41 & 1.32 & 0.70 & 1.50 & 1.24 & 1.57 & 1.41 & 1.56 & 1.78 \\
MI2 & 7.03 & 6.73 & 20.04 & 13.13 & 2.39 & 4.75 & 1.78 & 4.94 & 2.76 & 3.60 \\
MI3 & 2.15 & 2.27 & 2.57 & 2.54 & 1.87 & 2.09 & 1.80 & 2.37 & 1.75 & 0.90 \\
MI4 & 5.31 & 3.95 & 10.64 & 6.94 & 2.91 & 2.51 & 2.52 & 2.49 & 2.66 & 1.40 \\
MI5 & 0.90 & 0.94 & 2.47 & 2.30 & 0.42 & 0.53 & 0.40 & 0.59 & 0.43 & 0.20 \\
MI6 & 2.99 & 2.92 & 5.08 & 4.30 & 1.72 & 1.89 & 1.59 & 2.01 & 2.03 & 1.24 \\
\hline Tot M & 20.12 & 18.22 & 42.12 & 29.91 & 10.80 & 13.01 & 9.67 & 13.8 & 11.20 & 9.12 \\
\hline C & 10.67 & 7.56 & 7.99 & 6.55 & 12.87 & 8.44 & 12.91 & 9.13 & 12.90 & 7.79 \\
\hline MS1 & 16.37 & 21.04 & 16.26 & 19.46 & 13.99 & 19.39 & 13.7 & 19.02 & 17.56 & 19.75 \\
MS2 & 4.64 & 6.13 & 4.10 & 5.71 & 3.71 & 5.16 & 3.50 & 5.35 & 4.72 & 5.60 \\
MS3 & 0.99 & 1.80 & 1.58 & 3.01 & 0.61 & 1.32 & 0.58 & 1.30 & 0.83 & 1.72 \\
MS4 & 3.34 & 7.58 & 4.00 & 9.30 & 2.98 & 7.19 & 2.56 & 6.79 & 3.37 & 8.09 \\
\hline Tot MS & 25.33 & 36.55 & 25.93 & 37.47 & 21.29 & 33.06 & 20.35 & 32.47 & 26.48 & 35.16 \\
\hline NMS & 17.50 & 26.91 & 12.63 & 19.57 & 17.33 & 30.20 & 17.67 & 30.08 & 18.00 & 33.44
\end{tabular}

Table 1: Structural change, 1970:1994

Table 1 shows that: 1) the typical process of structural change takes place in Italy, as the weight of the agricultural sector declines with respect to Manufacturing and Services ${ }^{17}$ 2) this tendency is particularly remarkable in LOM; 3) in SOUTH, and especially SOUTH*, we witness on the contrary an expansion of the manufacturing sector which, however, does not reach levels comparable with the national average.

With respect to these broad tendencies, Sicily presents the following characteristics:

1. the share of employment in agriculture in 1994 is still relatively high with respect to ITA and LOM, but in line with SOUTH and SOUTH*. It is true, however, that the share in Agriculture in Sicily was $43 \%$ of the its level in 1970, so that it decreased at a slower pace than in SOUTH and, in particular, SOUTH*, in which the shares in 1994 are respectively $37 \%$ and $33 \%$ of their initial level.

\footnotetext{
${ }^{17}$ In Table 1 we indicate the total for the manufacturing sector and market services with, respectively, Tot $M$ and Tot $M S$.
} 
2. In Sicily the employment share in Manufacturing appears particularly low and decreasing with respect to its initial level. This is in contrast with the tendency observed in SOUTH and, in particular, in SOUTH*. ${ }^{18}$ The data on the manufacturing sector is relevant as, with respect for instance to other non-service sectors such as Agriculture and Construction, this is the sector in which technological advances may take place more significantly, ${ }^{19}$ and because it is the crucial sector for economic growth especially in the "take-off" stage where an economic structure based on agriculture is gradually abandoned (see, e.g., Rostow (1960)).

3. The absolute size of the construction sector appears in line with the corresponding values of the other macroregions and LOM but, with respect to the dimension of the manufacturing sector, it appears strikingly large. The ratio between employment in Construction and in Manufacturing in 1994 is, with respect to ITA, LOM, SOUTH, SOUTH* and SIC: $0.42,0.22,0.65,0.66,0.85$.

4. The public sector is remarkably larger than the national average and, in particular, than the value for LOM. In addition, it is larger than the corresponding value in SOUTH and SOUTH*.

Are these differences statistically significant? In order to answer this question, we run the following regression:

$$
S H A R E_{i, r, t}=\alpha+\beta_{0}(C \cdot S I C)+\beta_{1} S I C+\gamma \mathbf{S E C T}+\delta \mathbf{Y E A R}+\epsilon_{i, r, t},
$$

where $S H A R E_{i, r, t}$ is the employment share of sector $i$, in region $r$ in year $t, C$ is a dummy variable indicating sectors more favorable to crime, SIC is a dummy for Sicily, SECT and YEAR are, respectively, vectors of sectoral and calendar year dummies, $\epsilon_{i, r, t}$ is the disturbance term.

\footnotetext{
${ }^{18}$ For a concise description of the dynamics of the manufacturing sector in Sicily in this period, see, e.g., Helg et al. (2000).

${ }^{19}$ For example, ISTAT data show that the average incidence of investment in software on total gross fixed investment for the period 1970-1994 is, respectively for Agriculture, Manufacturing and Construction, $0.1 \%, 1.99 \%$ and $1.52 \%$. If the analysis is restricted to recent years, to be compatible with the discussion on technology in Section 3.2.3, these values amount to: $0.12 \%, 3.52 \%$ and $1.21 \%$.
} 
Before presenting the results, some explanation the specification of Eq. (1) is needed. The hypothesis in this paper is that, where the structure of the economy is biased towards certain sectors then organized crime, cœteris paribus, should be more pervasive. Hence, the structure of the economy should be included among the explanatory variables of organized crime diffusion. However, running a regression to directly capture this effect is complicated by the problem of obtaining the dependent variable, that is of measuring organized crime..$^{20}$

Hence, in Eq. (1) the supposedly high pervasiveness of organized crime in Sicily with respect to other regions is crudely measured by a dummy for Sicily, and this appears among the explanatory variables of the sectoral employment shares. Eq. (1), therefore, represents a tool to evaluate the correlation between organized crime and economic structure (but we will return on causality in Section 4). In particular, with this specification we aim at evaluating the robustness of the correlation between crime and employment shares and, therefore, include a number of dummies to capture possible omitted factors. The crucial coefficient in Eq. (1) is $\beta_{0}$ : if positive and statistically significant, it would indicate that there exists a robust positive correlation between pervasiveness of organized crime and the size of the "crime sectors'. Table 2 contains the results. ${ }^{21}$

\footnotetext{
${ }^{20}$ For example, in studies of convergence among Italian regions, some authors include a variable among the regressors in order to capture the effect of organized crime on the low growth of Southern regions (e.g., Tullio and Quarella (1999) utilize the number of murders). However, the intensity of specific crimes does not necessarily proxy for the pervasiveness of organized crime. A pervasive organized crime does not imply a high frequency of, e.g., violent crimes and, in addition, some crimes such as extortion may be severely underreported in the official statistics. The measurement of organized crime would therefore require a specific study, which goes beyond the purposes of this paper

${ }^{21}$ Our benchmark sector is MI2 in 1994.
} 


\begin{tabular}{|c|c|c|c|c|c|c|c|c|}
\hline & Ia & $\mathrm{Ib}$ & IIa & $\mathrm{IIb}$ & IIIa & IIIb & IVa & $\mathrm{IVb}$ \\
\hline$\hat{\beta_{0}}$ & $\begin{array}{l}0.0359 * * * \\
(0.0043)\end{array}$ & $\begin{array}{l}0.0349^{*} \\
(0.0183)\end{array}$ & $\underset{(0.0048)}{0.0410}$ *** & $\begin{array}{l}0.0425^{* *} \\
(0.0202)\end{array}$ & $\begin{array}{l}0.0239 * * * \\
(0.0048)\end{array}$ & $\begin{array}{l}0.0199 \\
(0.0203)\end{array}$ & $\begin{array}{l}0.0294 * * * \\
(0.0056)\end{array}$ & $\begin{array}{l}0.0277 \\
(0.0237)\end{array}$ \\
\hline year dummies & YES & YES & YES & YES & YES & YES & YES & YES \\
\hline crime dummy & CRIME1 & CRIME1 & CRIME2 & CRIME2 & CRIME3 & CRIME3 & CRIME4 & CRIME4 \\
\hline no. obs. & 7.000 & 560 & 7.000 & 560 & 7.000 & 560 & 7.000 & 560 \\
\hline adj. $R^{2}$ & 0.78 & 0.71 & 0.78 & 0.71 & 0.78 & 0.71 & 0.78 & 0.71 \\
\hline
\end{tabular}

Table 2: Estimation Eq. (1). Period of observation: 1970-1994. Regressions "a" utilize all data, regressions "b" utilize data from 1970 and 1994. Dependent variable: employment share. Standard errors in parenthesis. The symbols $*, * *, * * *$ denote significance at $10 \%, 5 \%, 1 \%$. CRIME1: dummy for sectors 1, 9, 10, 14. CRIME2: dummy for sectors 1, 9, 14. CRIME3: dummy for sectors 9, 10, 14 . CRIME4: dummy for sectors 9, 14 .

From Table 2 we note that, when the whole variability in the data is exploited, the estimated value of $\beta_{0}$ is always positive and highly statistically significant. ${ }^{22}$ The result is robust to different definitions of the "crime" sectors. ${ }^{23}$ When we consider only the initial and final year, we still obtain the predicted sign, although the parameter is measured more imprecisely. ${ }^{24}$

\footnotetext{
${ }^{22}$ Omitting the time dummies leaves the results unaffected.

${ }^{23}$ We considered as "crime" sectors, trying different combinations, first of all Construction and Non Market Services. In addition, we considered Agriculture, as a proxy of the relevance of "traditional" economic activities and Trade, Hotels and Public Establishment, as a service sector likely to be characterized by a low technological level, especially in contrast to Credit and Insurance where the skill and technological level are likely to be higher.

${ }^{24}$ Is this effect specific to Sicily or does it represent a tendency for the whole South? Reading Table 1 suggests that the differences in the economic structure we are discussing may actually characterize the South with respect to the rest of Italy. To answer these questions, we ran different specifications of Eq. (1) adding dummy variables for sets of Southern regions (e.g. all Southern regions or SOUTH* regions), also as interactive terms with the "crime" dummy. Results (not reported) show that, with all data: when we use the dummy CRIME3, (i) the coefficient $\hat{\beta}_{0}$ is still positive and significant, (ii) $\hat{\beta}_{0}$ is higher than the coefficient for $\left(\mathrm{C} \cdot \mathrm{SOUTH}^{*}\right)$, and a null of equality between the two coefficients is strongly rejected. This indicates that, with respect to a possible effect from regions in the South, Sicily has a differential effect and that, in particular, its effect is higher with respect to SOUTH* regions. When we use CRIME4, $\hat{\beta}_{0}$ is positive but marginally significant (p-value is $13 \%$ ); it is statistically significant and higher than the coefficient for (C - SOUTH*), but we cannot reject a null hypothesis of equality of the two coefficients (p-value of test of equality is 32\%). In both cases, with data from only 1970 and 1994,
} 
As a further test, we estimated Eq. (2):

$$
\Delta S H A R E_{i, r}=\alpha+\psi S H A R E_{i, r, 1970}+\beta_{0}(C \cdot S I C)+\beta_{1} S I C+\gamma \mathbf{S E C T}+\epsilon_{i, r},
$$

where $\triangle S H A R E_{i, r}$ is the variation in the share of sector $i$ in region $r$ between 1970 and 1994. The coefficient $\beta_{0}$, if positive, indicates by how much the dimension of "crime" sectors relatively increased more (or decreased less). The control for the initial share takes into account the differences in the initial structure and, if the estimated value of $\psi$ is negative, it would indicate a tendency to convergence in the structure of the regional economies. Plus, the use of the difference between 1970 and 1994 removes possible regional fixed effects, such as culture and social capital that could be relevant to the present analysis. $^{25}$

\begin{tabular}{l|cccc}
\hline & I & II & III & IV \\
\hline$\hat{\beta}_{0}$ & $0.0171^{*}$ & $\begin{array}{l}0.0286^{* *} \\
(0.0099)\end{array}$ & $\begin{array}{l}0.0156 \\
(0.0109)\end{array}$ & $\begin{array}{l}0.0322^{* *} \\
(0.0127)\end{array}$ \\
crime dummy & CRIME1 & CRIME2 & CRIME3 & CRIME4 \\
no. obs. & 280 & 280 & 280 & 280 \\
adj. $R^{2}$ & 0.92 & 0.92 & 0.92 & 0.92 \\
\hline
\end{tabular}

Table 3: Estimation Eq. (2). Period of observation: 1970-1994. Dependent variable: variation of employment share between 1970 and 1994. Standard errors in parenthesis. The symbols *,** denote significance at $10 \%$ and 5\%. CRIME1: dummy for sectors 1, 9, 10, 14. CRIME2: dummy for sectors 1, 9, 14. CRIME3: dummy for sectors 9, 10, 14. CRIME4: dummy for sectors 9, 14 .

Results in Table 3 show that, controlling for the initial share level, there exists evidence that "crime" sectors in Sicily had a relatively higher increase (or a relatively lower decline) with respect to the rest of Italy, as $\hat{\beta}_{0}$ is always positive and most of the times significant. The estimated values of $\psi$ (not reported) are always negative and significantly different from zero, indicating a broad tendency to convergence in employment shares the differential effect is positive but not significant, as well as the difference with respect to the coefficient for $\left(\mathrm{C} \cdot \mathrm{SOUTH}^{*}\right)$. These results reinforce those in Table 2 and suggest that, when we focus on share levels, including Agriculture in the "crime" dummy may not be entirely appropriate.

${ }^{25} \mathrm{Eq}$. (2) is obtained assuming that the equation for the employment shares in 1994 contains the initial conditions, i.e. shares in 1970, among the explanatory variables, while the effect of initial conditions in the equation for the shares in 1970 is absorbed by the intercept. 
across regions. Our result show that, however, in this process some sectors display a significantly different path and, for our purposes, this indicates that convergence in sectoral shares is associated to a bias in favor of "crime" sectors in Sicily. ${ }^{26}$ Overall, we find that the correlation between the diffusion of organized crime in Sicily and the structure of the Sicilian economy appears robust.

\subsubsection{On Firms' Size Distribution}

Figure 3 and Table 4 represent the firms' distribution by size (measured by the number of employees), based on data from ISTAT (2001). ${ }^{27}$

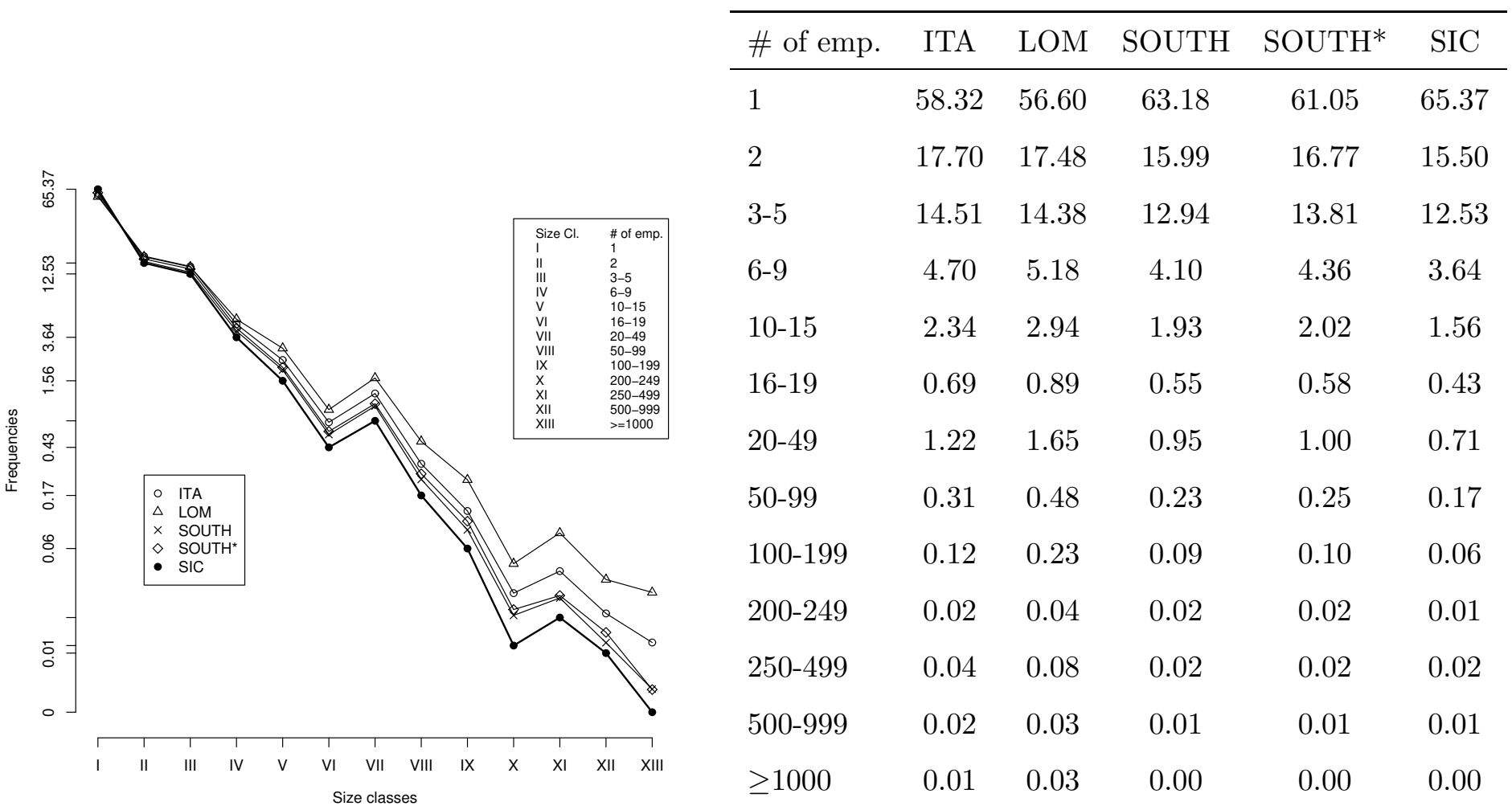

Figure 3: Firms' size distribution, $2001 \quad$ merical values

\footnotetext{
${ }^{26}$ We carried out tests similar to those described in Footnote 24. We find that: (i) the differential coefficient for Sicily with respect to a dummy for Southern regions is always positive but not significant (with CRIME2 the p-value is 0.11); (ii) the coefficient for Sicily is always higher than the one for SOUTH* regions, and a test of equality of their difference is rejected at 5\% with CRIME2 (while with CRIME1 the p-value of test of equality is 0.13 .). These result are consistent with the remark on the slower reduction of the Agricultural employment share in Sicily.

27 ISTAT (2001) contains data for the following sectors: Industry, Commerce, Other Services.
} 


\begin{tabular}{|c|c|c|c|c|c|c|c|c|c|}
\hline & $\mathrm{I}$ & II & III & IV & $\mathrm{V}$ & VI & VII & VIII & IX \\
\hline intercept & $\begin{array}{l}0.5832^{* * * *} \\
(0.0114)\end{array}$ & $\begin{array}{l}0.5548^{* * *} \\
(0.0096)\end{array}$ & $\begin{array}{l}0.5548^{* * * *} \\
(0.0084)\end{array}$ & $\begin{array}{l}0.6730^{* * * *} \\
(0.0139)\end{array}$ & $\begin{array}{l}0.63022^{* * *} \\
(0.0179)\end{array}$ & $\begin{array}{l}0.6233^{* * * *} \\
(0.0213)\end{array}$ & $\begin{array}{l}0.7482^{* * * *} \\
(0.0263)\end{array}$ & $\begin{array}{l}0.7142^{* * * *} \\
(0.0762)\end{array}$ & $\begin{array}{l}0.6598 * * * \\
(0.0807)\end{array}$ \\
\hline $\mathrm{SIC}$ & $\begin{array}{l}0.0705 \\
(0.0512)\end{array}$ & $\begin{array}{c}0.02190 \\
(0.0354)\end{array}$ & & & & & & & \\
\hline SOUTH & & $\begin{array}{l}0.0769 * * * \\
(0.0158)\end{array}$ & & & $\begin{array}{l}0.04138^{* * * *} \\
(0.01334)\end{array}$ & & & $\begin{array}{l}0.0158 \\
(0.0333)\end{array}$ & \\
\hline SOUTHC & & & $\begin{array}{l}0.1037^{* * * *} \\
(0.0168)\end{array}$ & & & $\begin{array}{l}0.0510^{* *} \\
(0.0205)\end{array}$ & & & $\begin{array}{l}0.0554 \\
(0.0404)\end{array}$ \\
\hline SOUTH* & & & $\begin{array}{l}0.0556^{* * *} \\
(0.0168)\end{array}$ & & & $\begin{array}{l}0.0388^{* *} \\
(0.0142)\end{array}$ & & & $\begin{array}{l}0.0198 \\
(0.0320)\end{array}$ \\
\hline FINDEP & & & & $\begin{array}{l}-0.0025^{* * *} \\
(0.0003)\end{array}$ & $\begin{array}{c}-0.0017^{* * *} \\
(0.0004)\end{array}$ & $\begin{array}{l}-0.0016 * * * \\
(0.0004)\end{array}$ & & & \\
\hline GVA99 & & & & & & & $\begin{array}{c}-0.0106^{* * *} \\
(0.0017)\end{array}$ & $\begin{array}{c}-0.0088^{*} \\
(0.0042)\end{array}$ & $\begin{array}{c}-0.0058 \\
(0.0044)\end{array}$ \\
\hline no. obs & 20 & 20 & 20 & 20 & 20 & 20 & 20 & 20 & 20 \\
\hline $\operatorname{adj} R^{2}$ & 0.04 & 0.58 & 0.67 & 0.71 & 0.80 & 0.80 & 0.67 & 0.66 & 0.69 \\
\hline
\end{tabular}

Table 5: Correlates of firms' size distribution. Dependent variable: share of firms in Size Class I. SOUTH is a dummy for southern regions, including Sicily; SOUTHC is a dummy for southern regions where organized crime is pervasive; SOUTH* is a dummy for southern regions where organized crime is not pervasive; GVA99 is per capita GVA in 1999; FINDEP is the measure of regional financial development proposed by Guiso et al. (2004). The symbols *,***** denote significance at 10\%, 5\%, $1 \%$.

It is possible to observe that Sicily has, on average, a lower frequencies of firms in each dimensional class but in the first, which includes firms with one employee. ${ }^{28}$ This holds not only with respect to Italy or Lombardy, but also with respect to SOUTH* which, although marginally, has a firm size distribution skewed towards the highest dimensional classes.

Table 5 summarizes the results of various regressions run to test the significance of the difference between firms' size distribution in Sicily and in other regions, also with respect to other possible correlates. ${ }^{29}$ In particular, we proxy the firms' size distribution by the share of firms in Size Class I, and use it a the dependent variable.

In Table 5, Models I-III only consider dummy variables. Model I show that the coefficient for Sicily is positive, but not statistically significant (the p-value is 0.18). Hence, Sicily does not seem to have a specific effect. ${ }^{30}$ However, from Models II and III there

\footnotetext{
${ }^{28}$ Data in Figure 3 are presented on a logarithmic scale in order to provide a better visual representation of low frequencies. The vertical axis, however, reports the actual frequency values.

${ }^{29}$ Tables 5 and 12 are based on OLS cross-section regressions with only one observation per region. Coefficients should be interpreted, for the reasons explained, as indicators of correlations.

${ }^{30}$ This result holds in general, so we omit the dummy for Sicily in the regressions that follow.
} 
appears a significant difference between Southern regions and the rest. In particular, regions in the south have a higher share of very small firms, but a difference emerges between SOUTH* regions and regions where organized crime is widespread, the latter being characterized by a larger share of very small firms. A test of equality of the coefficients for SOUTHC and SOUTH* is rejected at $5 \%$ level of confidence.

In regressions IV-IX we add two possible variables that may correlate with the firm size: ${ }^{31}$ the measure of financial development proposed in Guiso et al. (2004), and the level of per capita GVA in 1999 (the year in which data from ISTAT (2001) where collected), as a more general proxy for economic development. In particular, a higher level of financial development, cœteris paribus, should be associated to a higher firm size, as firms should be less credit constrained and therefore more capable of growing in regions where financial development is higher.

In Models IV-VI we observe that the coefficient of financial development is, as predictable, negative and significant. The regional dummies remain significant, albeit at a somewhat lower level. The difference between SOUTH* regions and the other southern regions remain with respect to the intercept, but we cannot reject the hypothesis of equality of the coefficients.

Finally, Models VII-IX show that the pattern in firms' size we are discussing is likely to be an aspect of the difference in economic development that exists in general. The regional dummies become non significant, albeit preserving their sign and relative magnitudes. ${ }^{32}$

To sum up, we find that there exists a significant difference between Southern Italy and the other regions in terms of the share of firms in Size Class I, that we use to proxy for the skewness of the firms' size distribution in favor of small firms. In this general tendency, we find some evidence that a further difference between SOUTH* regions and those where organized crime is pervasive is likely to exist, but the small dataset we used does not allow us to make stronger claims. This result appears as a part of the broad difference in the level of development between North and South regions (we defer to Section 4 further

\footnotetext{
${ }^{31}$ To preserve degrees of freedom, we consider them separately.

${ }^{32}$ Results in Table 5 are essentially confirmed if we proxy for the firms' size distribution by the average firm size, computed by the frequencies at various size classes multiplied for the central value of the class size (or class XIII, which is open, we arbitrarily set the value to 2000).
} 
discussion).

The following section focuses on the productivity dynamics over the period considered, aiming at providing more detailed information than the aggregate data presented in Figure 2, and on the technological level of Sicilian firms.

\subsubsection{On Productivity Dynamics and Technology}

A starting point to evaluate aggregate productivity dynamics with respect to the sectoral productivity dynamics can be the shift-share analysis. This type of exercise allows measuring how much the aggregate growth rate of productivity depends on productivity increases at sectoral level or on reallocation of workers across sectors and, therefore, connects the analyses of productivity and structural change, also providing preliminary information on the technological level characterizing the Sicilian economy.

Formally, aggregate productivity is decomposed as in Eq. (3):

$$
y=\frac{Y}{L}=\frac{\sum_{i} Y_{i}}{L}=\sum_{i} \frac{Y_{i}}{L_{i}} \cdot \frac{L_{i}}{L}=\sum_{i} y_{i} \cdot w_{i}
$$

where $y$ is aggregate productivity, $Y$ is total output, $L$ is total employment, $Y_{i}, L_{i}$ and $y_{i}$ are respectively output, employment and productivity in sector $i$, and $w_{i}$ is the employment share in sector $i$.

Productivity variation over a period, $\Delta y$, can be decomposed as in Eq. (4): ${ }^{33}$

$$
\Delta y=\sum_{j} \Delta y_{j} \cdot \bar{w}_{j}+\sum_{j} \Delta w_{j} \cdot \bar{y}_{j}
$$

where $\Delta y_{j}$ and $\Delta w_{j}$ are variations over a period (1970-1994 in our case), and $\bar{y}_{j}$ e $\bar{w}_{j}$ are the average values of productivity and of employment shares in sector $j$ (the average being simply computed between the initial and final values). In practice, the overall variation appears as a weighted average of sectoral productivity variations in individual sectors, weighted by the average employment shares, and of sectoral employment shares, weighted by the average sectoral productivity level.

The first and second terms of Eq. (4) respectively indicate the productivity growth effect, $(P G E)$, and share effect, $(S E)$. Tables 6-10 contain the results of the shift-share

\footnotetext{
${ }^{33}$ See, e.g., Bernard and Jones (1996).
} 
analysis for ITA, LOM, SOUTH, SOUTH* and SIC. ${ }^{34}$

\begin{tabular}{lcccccc}
\hline Sector & PGE & \% PGE & SE & \%SE & TE & \%TE \\
\hline AG & 0.31 & 11.23 & -0.32 & -11.25 & -0.01 & -0.02 \\
EN & -0.01 & -0.35 & -0.07 & -2.36 & -0.08 & -2.72 \\
MI1 & 0.06 & 2.30 & -0.02 & -0.74 & 0.04 & 1.56 \\
MI2 & 0.25 & 9.04 & -0.01 & -0.45 & 0.24 & 8.59 \\
MI3 & 0.08 & 2.82 & 0 & 0.14 & 0.08 & 2.96 \\
MI4 & 0.12 & 4.46 & -0.04 & -1.51 & 0.08 & 2.94 \\
MI5 & 0.05 & 1.63 & 0 & 0.07 & 0.05 & 1.70 \\
MI6 & 0.09 & 3.16 & 0 & -0.09 & 0.09 & 3.07 \\
C & 0.12 & 4.14 & -0.02 & -0.82 & 0.09 & 3.31 \\
MS1 & 0.26 & 9.39 & 0.22 & 7.82 & 0.48 & 17.21 \\
MS2 & 0.21 & 7.50 & 0.09 & 3.19 & 0.30 & 10.69 \\
MS3 & 0.04 & 1.56 & 0.16 & 5.58 & 0.20 & 7.14 \\
MS4 & -0.04 & -1.50 & 0.67 & 24.07 & 0.63 & 22.56 \\
NMS & 0.06 & 2.10 & 0.53 & 18.89 & 0.59 & 20.99 \\
\hline Total & 1.61 & 57.47 & 1.19 & 42.53 & 2.80 & 100 \\
\hline
\end{tabular}

Table 6: Shift-share analysis, ITA

\begin{tabular}{lcccccc}
\hline Sector & PGE & \% PGE & SE & \%SE & TE & \% TE \\
\hline AG & 0.10 & 3.94 & -0.07 & -2.83 & 0.03 & 1.11 \\
EN & 0.19 & 7.54 & -0.26 & -10.6 & -0.08 & -3.06 \\
MI1 & 0.05 & 2.17 & -0.03 & -1.35 & 0.02 & 0.82 \\
MI2 & 0.64 & 25.71 & -0.31 & -12.4 & 0.33 & 13.31 \\
MI3 & 0.07 & 2.92 & 0 & -0.04 & 0.07 & 2.87 \\
MI4 & 0.22 & 8.67 & -0.1 & -3.96 & 0.12 & 4.71 \\
MI5 & 0.10 & 4.10 & -0.01 & -0.29 & 0.09 & 3.81 \\
MI6 & 0.12 & 5.00 & -0.03 & -1.17 & 0.10 & 3.83 \\
C & 0.04 & 1.81 & 0 & -0.18 & 0.04 & 1.63 \\
MS1 & 0.29 & 11.78 & 0.16 & 6.26 & 0.45 & 18.04 \\
MS2 & 0.14 & 5.73 & 0.09 & 3.50 & 0.23 & 9.23 \\
MS3 & 0.04 & 1.71 & 0.21 & 8.31 & 0.25 & 10.02 \\
MS4 & -0.09 & -3.8 & 0.67 & 26.97 & 0.57 & 23.17 \\
NMS & -0.04 & -1.44 & 0.30 & 11.95 & 0.26 & 10.51 \\
\hline Total & 1.88 & 75.82 & 0.6 & 24.18 & 2.48 & 100 \\
\hline
\end{tabular}

Table 7: Shift-share analysis, LOM

\footnotetext{
${ }^{34}$ Data in Tables $6-10$ are average annual growth rates, obtained by dividing the growth rates over the period by the period length. This simplyfies the computation, but introduces a slight bias in the reported values. The term $T E$ indicates the Total Effect.
} 


\begin{tabular}{lcccccc}
\hline Sector & PGE & \% PGE & SE & \%SE & TE & $\%$ TE \\
\hline AG & 0.46 & 15.78 & -0.47 & -16.30 & -0.02 & -0.52 \\
EN & -0.01 & -0.52 & 0.05 & 1.87 & 0.04 & 1.35 \\
MI1 & 0.05 & 1.73 & -0.01 & -0.45 & 0.04 & 1.28 \\
MI2 & 0.14 & 4.76 & 0.13 & 4.44 & 0.27 & 9.20 \\
MI3 & 0.10 & 3.36 & 0.01 & 0.34 & 0.11 & 3.70 \\
MI4 & 0.08 & 2.85 & -0.01 & -0.22 & 0.08 & 2.63 \\
MI5 & 0.02 & 0.7 & 0.01 & 0.24 & 0.03 & 0.93 \\
MI6 & 0.06 & 2.08 & 0.01 & 0.35 & 0.07 & 2.43 \\
C & 0.15 & 5.10 & -0.03 & -1.08 & 0.12 & 4.02 \\
MS1 & 0.25 & 8.74 & 0.28 & 9.54 & 0.53 & 18.28 \\
MS2 & 0.22 & 7.63 & 0.09 & 3.26 & 0.31 & 10.88 \\
MS3 & 0.04 & 1.40 & 0.16 & 5.41 & 0.20 & 6.81 \\
MS4 & -0.12 & -4.13 & 0.67 & 23.34 & 0.55 & 19.21 \\
NMS & 0.04 & 1.47 & 0.53 & 18.32 & 0.57 & 19.79 \\
\hline Total & 1.47 & 50.96 & 1.42 & 49.04 & 2.89 & 100 \\
\hline
\end{tabular}

Table 8: Shift-share analysis, SOUTH

\begin{tabular}{lcccccc}
\hline Sector & PGE & \% PGE & SE & \%SE & TE & \%TE \\
\hline AG & 0.56 & 17.52 & -0.54 & -17.16 & 0.01 & 0.36 \\
EN & -0.01 & -0.46 & 0.10 & 3.10 & 0.08 & 2.64 \\
MI1 & 0.06 & 1.81 & -0.01 & -0.35 & 0.05 & 1.46 \\
MI2 & 0.16 & 5.07 & 0.17 & 5.43 & 0.33 & 10.51 \\
MI3 & 0.10 & 3.07 & 0.03 & 0.92 & 0.13 & 3.99 \\
MI4 & 0.10 & 3.07 & 0.01 & 0.16 & 0.10 & 3.23 \\
MI5 & 0.02 & 0.69 & 0.01 & 0.38 & 0.03 & 1.06 \\
MI6 & 0.07 & 2.24 & 0.02 & 0.68 & 0.09 & 2.93 \\
C & 0.15 & 4.67 & -0.02 & -0.70 & 0.13 & 3.97 \\
MS1 & 0.25 & 8.02 & 0.28 & 8.86 & 0.54 & 16.88 \\
MS2 & 0.21 & 6.66 & 0.12 & 3.78 & 0.33 & 10.44 \\
MS3 & 0.07 & 2.10 & 0.16 & 4.93 & 0.22 & 7.03 \\
MS4 & -0.12 & -3.86 & 0.67 & 21.26 & 0.55 & 17.41 \\
NMS & 0.05 & 1.42 & 0.53 & 16.69 & 0.57 & 18.11 \\
\hline Total & 1.65 & 52.02 & 1.52 & 47.98 & 3.17 & 100 \\
\hline
\end{tabular}

Table 9: Shift-share analysis, SOUTH*

\begin{tabular}{lcccccc}
\hline \hline Sector & PGE & \%PGE & SE & \%SE & TE & \%TE \\
\hline AG & 0.37 & 12.11 & -0.36 & -11.91 & 0.01 & 0.19 \\
EN & 0.07 & 2.24 & 0.07 & 2.36 & 0.14 & 4.60 \\
MI1 & 0.03 & 1.03 & 0 & 0.15 & 0.04 & 1.18 \\
MI2 & 0.06 & 2.04 & 0.03 & 0.94 & 0.09 & 2.97 \\
MI3 & 0.11 & 3.48 & -0.08 & -2.64 & 0.03 & 0.84 \\
MI4 & 0.02 & 0.58 & -0.01 & -0.41 & 0.01 & 0.17 \\
MI5 & 0.03 & 1.12 & -0.02 & -0.55 & 0.02 & 0.56 \\
MI6 & 0.06 & 1.94 & -0.03 & -0.85 & 0.03 & 1.09 \\
C & 0.21 & 6.77 & -0.05 & -1.67 & 0.16 & 5.10 \\
MS1 & 0.41 & 13.45 & 0.09 & 2.99 & 0.50 & 16.44 \\
MS2 & 0.25 & 8.29 & 0.05 & 1.74 & 0.31 & 10.04 \\
MS3 & -0.03 & -0.90 & 0.18 & 5.86 & 0.15 & 4.95 \\
MS4 & -0.27 & -8.76 & 0.91 & 29.87 & 0.65 & 21.11 \\
NMS & 0.08 & 2.64 & 0.86 & 28.12 & 0.94 & 30.76 \\
\hline Total & 1.41 & 46.02 & 1.65 & 53.98 & 3.06 & 100 \\
\hline
\end{tabular}

Table 10: Shift-share analysis, SIC 
From Tables $6-10$ we note that:

1. the highest values for productivity growth is found in SOUTH*.

2. The value for Sicily is higher than the national value. ${ }^{35}$

3. Productivity growth in Sicily is based by about $54 \%$ on reallocation of workers across sectors. This stands in sharp contrast with ITA e LOM, and the value is in any case higher the one computed for SOUTH and SOUTH*. Productivity gains, therefore, play a distinctly weaker role in Sicily than in the other regions and macroregions considered..$^{36}$

4. A relevant part of increases in productivity, about $28 \%$, in Sicily has to be ascribed to the reallocation of workers to the public sector. This value is again very different from that of ITA e LOM and is considerably higher than the one computed for SOUTH and SOUTH* ${ }^{37}$

From this analysis, therefore, the productivity performance of Sicily has to be reassessed for at least two reasons. Firstly, productivity in strict sense has a stagnant dynamics, which suggests the likely presence of a low technological level of Sicilian firms. ${ }^{38}$ Secondly, the public sector, when representing an important source of jobs in a period of strong structural change as the one under investigation here, may bias the datum on overall productivity growth. Value added in the public sector is essentially measured by salaries, and therefore it may not reflect actual productivity gains based on technology, human capital, etc. ${ }^{39}$

\footnotetext{
${ }^{35}$ This, however, did not allow Sicily to fill the initial productivity gap, as shown in Figure 2.

${ }^{36}$ Note in particular the contribution of MI2 in LOM, highlightning the importance of the metal machinery sector for productivity, even in an economy facing an overall reduction of the manufacturing sector.

${ }^{37}$ In general, NMS provide smaller contributions to productivity than some market services. The latter, however, give mixed contributions, as Tables 6-10 show.

${ }^{38}$ Clearly, productivity is in principle determined by several variables, besides technology: the capital stock, the level of competition, the availability of human capital, etc. A thourough analysis of this issue, however, is beyond the scope of the present work.

${ }^{39}$ In addition, as Alesina et al. (2001) show, approximately $50 \%$ of public employment in Southern regions can be interpreted as redistribution from other regions. This confirms that the measure of
} 
Since having a low technological level has been indicated as a factor which may favor criminal organizations, in Table 11 we provide further elements to assess the technological level of Sicilian firms.

\begin{tabular}{lcc|cc|cc|cc|cc|cc|cc|cc}
\hline & \multicolumn{4}{c}{1} & \multicolumn{4}{c}{2} & \multicolumn{3}{c}{3} & \multicolumn{3}{c}{4} & \multicolumn{3}{c}{5} & \multicolumn{3}{c}{6} \\
\hline & abs & rel & abs & rel & abs & rel & abs & rel & abs & rel & abs & rel & abs & rel & abs & rel \\
\hline ITA & 0.28 & 1 & 0.42 & 1 & 0.52 & 1 & 1.78 & 1 & 2.08 & 1 & 73.8 & 1 & 68.70 & 1 & 46.80 & 1 \\
LOM & 0.52 & 1.89 & 0.87 & 2.09 & 1.00 & 1.93 & 4.22 & 2.38 & 4.68 & 2.25 & 89.00 & 1.21 & 86.20 & 1.25 & 63.60 & 1.36 \\
SOUTH & 0.13 & 0.48 & 0.20 & 0.49 & 0.28 & 0.53 & 0.81 & 0.46 & 0.95 & 0.46 & NA & NA & NA & NA & NA & NA \\
SOUTH* & 0.14 & 0.51 & 0.21 & 0.51 & 0.28 & 0.54 & 0.78 & 0.44 & 0.90 & 0.43 & 71.13 & 0.96 & 75.03 & 1.09 & 47.47 & 1.01 \\
SIC & 0.13 & 0.47 & 0.22 & 0.52 & 0.31 & 0.6 & 0.92 & 0.52 & 1.10 & 0.62 & 62.50 & 0.85 & 51.10 & 0.74 & 28.7 & 0.61 \\
\hline
\end{tabular}

Table 11: Indicators of technological level. Keys: 1) R\&D workers/private sector employment; 2) R\&D expenditure/total regional GVA; 3) R\&D expenditure/private sector regional GVA; 4) R\&D expenditure/total regional fixed gross investments; 5) R\&D expenditure/private sector regional fixed gross investments; 6) \% of firms with at least one PC; 7) \% of firms with at least one internet connection; 8) $\%$ of firms with at least one server. Indicators are expressed in absolute ("abs") and relative ("rel") values with respect to national average. Data for columns 1)-5) are from ISTAT and refer to the period 2002-2003. Data for columns 6)-8) are from Confcommercio (2007) and refer to 2006.

The values in Table 11, referred to recent years, ${ }^{40}$ show that, if we measure the technological level of firms by their R\&D intensity, values for Sicily do not differ much from values for SOUTH and SOUTH* which, altogether, appear strikingly far from the values of ITA and, especially, LOM. However, when we measure the technological level by the penetration of Information and Communication technologies, here proxied by the use of PCs, internet and servers, we note that Sicilian firms have a much lower technological level than firms in SOUTH*. ${ }^{41}$

However, since R\&D is not necessarily a good proxy for the technological level of the aggregate productivity in a Southern region such as Sicily may not reflect an actual capacity to generate value added locally.

${ }^{40}$ The choice of this period is dictated by the availability of data.

${ }^{41}$ Data are from Confcommercio (2007) and refer to a survey conducted on firms with less than 50 employees, active in the sectors of Wholesale and Retail trade, Public Establishment and Services. With the available data, it was not possible to compute the value for SOUTH, while the value for SOUTH* has been computed considering: ABR, MOL and SAR. I am very grateful to Andreas Schwalm from Assintel for providing me with the data. 
firms, in particular small firms, ${ }^{42}$ and data on ICT penetration are not complete, as a further variable providing information on firms' technological level, we consider in Table 12 data on exports.

\begin{tabular}{lcc|cc}
\hline \hline & \multicolumn{2}{c}{8} & \multicolumn{2}{c}{9} \\
\hline & abs & rel & abs & rel \\
\hline ITA & 18.73 & 1 & 23.44 & 1 \\
LOM & 30.17 & 1.61 & 34.69 & 1.48 \\
SOUTH & 11.56 & 0.62 & 15.63 & 0.67 \\
SOUTH* & 15.70 & 0.84 & 21.01 & 0.90 \\
SIC & 7.91 & 0.42 & 11.40 & 0.49 \\
\hline
\end{tabular}

Table 12: Exports at regional level. Keys: 8) exports/total regional GVA; 9) export/private sector regional GVA. Indicators are expressed in absolute and relative values with respect to national average (indicated by "abs" and "rel'). Data are from ISTAT and refer to the period 2002-2004.

The capacity to export is recognized as a good indicator of overall firms' quality, which includes their technological level. As Bernard and Jensen (1999), pp. 2-3, succinctly point out: "Good firms become exporters ... exporters are larger, more productive, more capital-intensive, more technology intensive, and pay higher wages". Table 12 shows that the capacity of Sicilian firms to export is dramatically lower not only than the Italian average and LOM, but also than SOUTH and SOUTH*. Table 13 reports the results of regressions carried out to check the statistical significance of these differences.

\footnotetext{
${ }^{42}$ See, e.g., Sterlacchini (1999). Other possible measures include the purchase of innovative capital, expenditures on design, engineering and post-production.
} 


\begin{tabular}{|c|c|c|c|c|c|c|c|}
\hline & I & II & III & IV & V & VI & VII \\
\hline intercept & $\begin{array}{l}19.296^{* * *} \\
(2.346)\end{array}$ & ${ }_{(2.531)}^{23.504^{* * *}}$ & ${ }_{(2.410)}^{23.504^{* * *}}$ & $\begin{array}{l}4.9831 \\
(3.9525)\end{array}$ & $\begin{array}{c}10.5011 \\
(6.1222)\end{array}$ & $\begin{array}{c}11.7040 \\
(7.3685)\end{array}$ & $\begin{array}{l}-68.7183^{* *} \\
(29.1346)\end{array}$ \\
\hline SIC & $\begin{array}{l}-11.387 \\
(10.494)\end{array}$ & $\begin{array}{l}-4.175 \\
(9.372)\end{array}$ & & & & & \\
\hline SOUTH & & $-{ }_{(4.169)}-11.420 * *$ & & & $\begin{array}{l}-5.3418 \\
(4.5588)\end{array}$ & & \\
\hline SOUTHC & & & $\begin{array}{c}-16.084^{* * * *} \\
(4.819)\end{array}$ & & & $\begin{array}{c}-7.0030 \\
(7.0719)\end{array}$ & \\
\hline SOUTH* & & & $\begin{array}{l}-7.799 \\
(4.819)\end{array}$ & & & $\begin{array}{c}-4.9016 \\
(4.8904)\end{array}$ & \\
\hline FINDEP & & & & $\begin{array}{l}0.3918^{* * * *} \\
(0.1011)\end{array}$ & $\begin{array}{l}0.2954^{* *} \\
(0.1295)\end{array}$ & $\begin{array}{l}0.2681 \\
(0.1591)\end{array}$ & \\
\hline GVA & & & & & & & $\underset{(4.2557)}{11.3554^{* *}}$ \\
\hline $\mathrm{GVA}^{2}$ & & & & & & & $\begin{array}{c}-0.3433^{* *} \\
(0.1475)\end{array}$ \\
\hline no. obs & 20 & 20 & 20 & 20 & 20 & 20 & 20 \\
\hline $\operatorname{adj} R^{2}$ & 0.01 & 0.27 & 0.34 & 0.42 & 0.44 & 0.40 & 0.42 \\
\hline
\end{tabular}

Table 13: Correlates of export propensity. Dependent variable: exports/total GVA (average 2002-2004). SOUTH is a dummy for southern regions, including Sicily; SOUTHC is a dummy for southern regions where organized crime is pervasive; SOUTH* is a dummy for southern regions where organized crime is not pervasive; GVA is average per capita GVA in 2002-04; GVA ${ }^{2}$ is GVA squared; FINDEP is the measure of regional financial development proposed by Guiso et al. (2004). The symbols *,**,*** denote significance at $10 \%, 5 \%, 1 \%$.

Models I-III in Table 13 show that the export propensity in Southern regions is significantly lower than the intercept, although Sicily does not feature a specific difference. However, as shown in Model III, this difference appears essentially ascribable to Southern regions where organized crime is pervasive, as the coefficient for SOUTH* regions is marginally significant (the p-value for SOUTH* in Model III is $12 \%$ ). ${ }^{43}$ When we control for financial development, ${ }^{44}$ the dummies assume the expected sign but become non significant. Finally, per capita GVA still appears as a strong correlate of export propensity, albeit in a nonliner fashion. ${ }^{45}$

Overall, we found that firms where organized crime is pervasive, are likely to have a low technological level, although the small dataset used and the results from the consideration

\footnotetext{
${ }^{43}$ The p-value of a test of equality of the coefficients for SOUTH* and SOUTHC is $18 \%$.

${ }^{44} \mathrm{On}$ the assumption that where financial development is high, firms are may increase their "quality" and are more likely to become exporters.

${ }^{45}$ No dummies turned out to be significant in presence of per capita GVA.
} 
of correlates such as financial development suggest some caution. This is consistent with the prediction that organized crime may more likely spread where the technological level of the firms is low. Moreover, as long as this is associated to a low export propensity, it can also have a bearing on the issue of the demand for protection, as we discuss in Section 4.

\section{Conclusions}

In this paper we studied an aspect so far overlooked in explanations of the diffusion and persistence of organized crime. We refer to the structure of the economy, on the hypothesis that, where the economy has certain characteristics, organized crime can spread more easily. The main result is that the structure of the Sicilian economy has features that represent favorable preconditions for the intrusion of organized crime in the economic activity. This constitutes an alternative to explanations of organized crime based on cultural and social factors.

In particular, the Sicilian economy appears characterized by:

1. a relatively high dimension of traditional sectors, such as the Construction sector, whose activity has a high degree of territorial specificity;

2. a distribution of firms' size relatively skewed towards small firms;

3. a relatively low technological level;

4. a relatively large dimension of the public sector.

In Section 3.2.1 we showed that, in terms of employment shares dynamics, there emerges a specificity for the Sicilian economy which is robust to various controls. Instead, using a much smaller database, in Sections 3.2.2 and 3.2.3 we have identified some statistically significant differences between Southern regions as a group and the rest of Italy. In particular, Southern regions where organized crime is not widespread do indeed present characteristics that make them less permeable, although the results on variables such as 
the level of financial development suggest that the picture is likely to be more complicated. However, we believe that analyses of organized crime, in particular of its diffusion and persistence, should include the consideration for the structure of the economy. ${ }^{46}$

The analysis has been conducted assuming a direction of causality going from the economic structure to organized crime, although, for the reasons explained, we resorted to the identification of robust correlations to support this idea. However, it is certainly true that causality may also run in the opposite direction, producing a vicious circle of persistent organized crime activities, and of low economic development.

This would occur if, in presence of organized crime, the economic structure endogenously became biased toward shapes more favorable to criminal organizations. Part of the results in this paper could already be interpreted in this sense. For example, the presence of organized crime may cause firms to remain small and not to invest in technology because of the risk of expropriation by the Mafia, and the low level of competition generated by the Mafia may further reduce stimuli to innovate. In addition, when firms are focused on local instead of foreign markets, as we showed is the case in Sicily and in the other "crime" regions, this may increase firms' incentives to buy protection in order to become or remain insulated from internal competition. ${ }^{47}$

Furthermore, the economic structure of Sicily and, possibly, of the other regions where organized crime is widespread, is likely to be associated to low economic growth as the latter depends, as almost universally recognized, on technological progress and human capital. In other words, Sicily could be trapped in locally stable low-income equilibrium, typically defined "poverty trap" (see, e.g., Barro and Sala-i-Martin (2004), pp.74-77) with feedbacks going from the economic structure to organized crime and vice versa.

Among the directions of further research we can list: (i) a thourough analysis aiming at identifying causal relationships between the structure of the economy, the presence of organized crime and other indicators of economic development; (ii) a corroboration of the results in Sections 3.2.2 and 3.2.3 which, in the present paper, have been obtained with a small dataset.

\footnotetext{
${ }^{46}$ For an economic explanation of the origins of organized crime in Sicily, see Bandiera (2003).

${ }^{47}$ I owe this remark to Federico Varese.
} 


\section{Acknowledgments}

This research was conducted for the project on "The Costs of Illegality", sponsored by the "Fondazione Chinnici" (http://www.fondazionechinnici.it/). I wish to thank the members of the research group (in particular Adam Asmundo, Antonio La Spina, Maurizio Lisciandra, Rodolfo Signorino and Chiara Talamo) for various discussions and the Fondazione Chinnici. I wish also to thank Anna Pinna and Andreas Schwalm for help with the data, and Simona Benedettini, Michele Battisti, Carlo Bianchi, Salvatore Modica, Federico Varese and two anonymous referees for very helpful comments and suggestions. Usual caveat applies.

\section{References}

Alesina, A. S. Danninger and M. Rostagno (2001), "Redistribution Through Public Employment: the Case of Italy", IMF Staff Papers 48.

Alexander, B. (1997), "The Rational Racketeer: Pasta Protection in Depression Era Chicago", Journal of Law and Economics 40, 175-202.

Bandiera, O. (2003), "Land Reform, the Market for Protection, and the Origins of the Sicilian Mafia: Theory and Evidence", Journal of Law, Economics and Organization 19, 218-244.

Barro, R. J. and X. Sala-i-Martin (2004), Economic Growth. Second Edition, MIT Press.

Bernard, A. B., and J. B. Jensen (1999), "Exceptional Exporter Performance: Cause, Effect or Both?", Journal of International Economics 47, 1-25.

Bernard, A. B., and C. I. Jones (1996), "Productivity and Convergence Across U.S. States and Industries", Empirical Economics 21, 113-35.

CENSIS (2007), XLI Rapporto annuale sulla situazione del paese, Franco Angeli.

Confcommercio (2007), Il digital divide nella micro e piccola impresa italiana. 
Del Monte A. and E. Papagni (1998), "The Determinants of Corruption in Italy: Regional Panel Data Analysis", European Journal of Political Economy 23, 379-396.

Fiorentini, G. (2000), "Organized Crime and Illegal Markets", in Bouckaert, B. and G. De Geest (eds.), Encyclopedia of Law and Economics, Elgar.

Gambetta, D. (1993), The Sicilian Mafia: the Business of Private Protection, Harvard University Press.

Gambetta, D. and P. Reuter (1995), "Conspiracy Among the Many: the Mafia in Legitimate Industries", in Fiorentini, G. and S. Peltzman (eds.), The Economics of Organised Crime, Cambridge University Press.

Guiso, L., P. Sapienza and L. Zingales (2004), "Does Local Financial Development Matter?", Quarterly Journal of Economics 119, 929-969.

Helg R., G. Peri and G. Viesti (2000), "Abruzzo and Sicily: Catching Up and Lagging Behind", European Investment Bank Papers 5, 61-86.

ISTAT (1996), La formazione del personale nelle imprese.

ISTAT (2001), Censimento generale dell'industria e dei servizi.

Kaufman, D., A. Kraay and M. Mastruzzi (2006), "Governance Matters V: Aggregate and Individual Governance Indicators for 1996-2005", World Bank Policy Research Working Paper 4012.

Kelly, R. J. (1999), The Upperworld and the Underworld. Case Studies of Racketeering and Business Infiltrations in the United States, Kluwer Academic.

Lavezzi, A. M. (2008), "Struttura economica e vulnerabilitá al crimine organizzato in Sicilia", in A. La Spina (ed.), I costi dell'illegalitá. Mafia ed estorsioni in Sicilia, Il Mulino.

Leonardi, R. (2002), "Regional Development in Italy: Social Capital and the Mezzogiorno", Oxford Review of Economic Policy 11, 165-179. 
Nelson, R. and E. Phelps (1966), "Investment in Humans, Technological Diffusion and Economic Growth", American Economic Review 61, 69-75.

Putnam, R. D. (1993), Making Democracy Work: Civic Traditions in Modern Italy, Princeton University Press.

Reuter, P. (1987), Racketeering in Legitimate Industries. A Study in the Economics of Intimidation, RAND Corporation.

Rostow, W. W. (1960), The Stages of Economic Growth, Oxford University Press.

Schelling, T. C. (1967), "Economics and Criminal Enterprise", The Public Interest 7, 61-78. Reprinted in T. C. Schelling (1984), Choice and Consequences, Harvard University Press.

Schelling, T. C. (1971), "What is the Business of Organized Crime?", Journal of Public Law 20, 71-84. Reprinted in T. C. Schelling (1984), Choice and Consequences, Harvard University Press.

Schneider, J. C. and P. T. Schneider (2003), Reversible Destinity. Mafia, Antimafia and the Struggle for Palermo, University of California Press.

Sterlacchini, A. (1999), "Do Innovative Activities Matter to Small Firms in non-R\&Dintensive Industries? An Application to Export Performance", Research Policy 28, 819832.

Tullio, G. and S. Quarella (1999), "Convergenza economica tra le regioni italiane: il ruolo della criminalit e della spesa pubblica, 1960-1993", Rivista di Politica Economica 89, $77-128$.

Varese, F. (2006), "How Mafias Migrate: The Case of the 'Ndrangheta in Northern Italy", Law \& Society Review 40, 411-444. 


\section{A Regions and Sectors' List}

\begin{tabular}{|c|c|c|c|c|c|c|c|c|c|}
\hline \multicolumn{7}{|c|}{ Regions } & \multicolumn{3}{|r|}{ Sectors } \\
\hline$\#$ & Key & Region & & & & & $\#$ & Key & Sector \\
\hline 1 & PIE & Piedmont & ITA & $\mathrm{CN}$ & & & 1 & AG & Agriculture \\
\hline 3 & $\mathrm{LOM}$ & Lombardy & ITA & $\mathrm{CN}$ & & & 3 & MI1 & Minerals and non-metallic mineral products \\
\hline 4 & TAA & Trentino-Alto Adige & ITA & $\mathrm{CN}$ & & & 4 & MI2 & Metal products and machinery and transport equipment \\
\hline 7 & LIG & Liguria & ITA & $\mathrm{CN}$ & & & 7 & MI5 & Paper, and printing products \\
\hline 8 & EMR & Emilia Romagna & ITA & $\mathrm{CN}$ & & & 8 & MI6 & Wood, rubber and other industrial products \\
\hline 9 & TOS & Tuscany & ITA & $\mathrm{CN}$ & & & 9 & $\mathrm{C}$ & Building and construction sector \\
\hline 10 & UMB & Umbria & ITA & $\mathrm{CN}$ & & & 10 & MS1 & Trade, hotels and public establishment \\
\hline 14 & MOL & Molise & ITA & & SOUTH & SOUTH* & 14 & NMS & Non-market services \\
\hline 15 & CAM & Campania & ITA & & SOUTH & & & & \\
\hline 16 & PUG & Apulia & ITA & & SOUTH & & & & \\
\hline 17 & BAS & Basilicata & ITA & & SOUTH & SOUTH* & & & \\
\hline 18 & CAL & Calabria & ITA & & SOUTH & & & & \\
\hline 19 & SAR & Sardinia & ITA & & SOUTH & SOUTH* & & & \\
\hline 20 & SIC & Sicily & & & & & & & \\
\hline
\end{tabular}

Table 14: Regions and Sectors' list. Regions are referred to one of the macroregions (ITA, CN, SOUTH, SOUTH*) 